\title{
A polymeric co-assembly of subunit vaccine with polyoxometalates induces enhanced immune responses
}

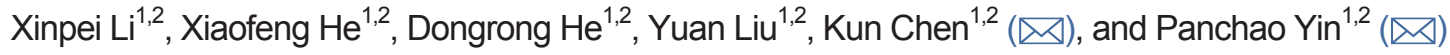 \\ ${ }^{1}$ South China Advanced Institute for Soft Matter Science and Technology, School of Molecular Science and Engineering, South China University of \\ Technology, Guangzhou 510640, China \\ ${ }^{2}$ Guangdong Provincial Key Laboratory of Functional and Intelligent Hybrid Materials and Devices, South China University of Technology, \\ Guangzhou 510640, China
}

(c) Tsinghua University Press and Springer-Verlag GmbH Germany, part of Springer Nature 2021

Received: 21 October 2021 / Revised: 16 November 2021 / Accepted: 17 November 2021

\begin{abstract}
Long-lasting protective immune responses are expected following vaccination. However, most vaccines alone are inability to evoke an efficient protection. The combinatory administration of adjuvants with vaccines is critical for generating the enhanced immune responses. Herein, with biocompatible poly(4-vinylpyridine) (P4VP) as template, $2.5 \mathrm{~nm}$ iron/molybdenum oxide cluster, $\left\{\mathrm{Mo}_{72} \mathrm{Fe}_{30}\right\}$, is applied as an adjuvant to co-assemble with antigens of Mycobacterium bovis via hydrogen bonding at molecular scale. Molecular scale integration of the antigens and $\left\{\mathrm{Mo}_{72} \mathrm{Fe}_{30}\right\}$ and their full exposure to body fluid media contribute to the augmentation of both humoral and cellular immune responses of the vaccines after inoculation in mice. Anti-inflammatory factor IL-10 gradually increases after 2 weeks followed by a final back to normal level by the 5 th week. The balance between proinflammatory cytokines and anti-inflammatory factors suggests that immune system can be activated in the early stage of infection by the antigens carried by the supra-particles and secrete acute inflammatory factors for host defense and antiinflammatory factors for immune protection.
\end{abstract}

\section{KEYWORDS}

co-assembly, immune response, metal oxide cluster, supramolecular interaction, vaccine adjuvant

\section{Introduction}

Since the worldwide pneumonia outbreak of coronavirus disease 2019 (COVID-19), researchers shoulder the mission of stemming its spread and currently, most of efforts are focused on the development of new detection methods [1] and antiviral drugs, especially, safe and effective vaccines. The COVID-19 pandemic is not a rare exception in human history while the tuberculosis (TB) has afflicted humans since the 18th centuries. Bacillus Calmette Guérin (BCG) vaccine has been proven its protection from COVID-19 and TB since nonspecific immune stimulation is quite useful to organisms to repel most potential pathogens before they cause detectable signs and symptoms of disease [2-4]. It is wellknown that live-attenuated BCG vaccine (from Mycobacterium bovis (M. bovis)) is effective in protecting young children from severe TB disease; however, it is less efficacious for adults [3]. In essence, systematically administered vaccines like BCG fail to generate adequate protective responses at mucosal surfaces [5]. Nowadays, complex nanoparticles (NPs) carrying antigens are of particular interests for vaccine development because of their adjuvant effects on the modulation of immune response [6-10]. NPs have been extensively explored to cope with the instability and toxicity frequently interrelated with the administration of soluble molecules [11]. Moreover, the conjunction of antigens to the surfaces of NPs is favorable to B-cell activation since comparatively higher level of antigens can be delivered to antigen presenting cells (APCs) [9,12-14]. The delivery of antigens in particulate form of assemblies also shows the potential to induce Tcell activation following vaccination [15]. Therefore, general approaches are urgently needed for the controllable co-assembly of antigens and appropriate NPs to required morphologies for enhanced immune responses.

Cellular immunity, paired with humoral immunity, is a critical part of a healthy and functioning immune system against infection and reinfection by bacteria or virus $[16,17]$. Most NPs are effective in inducing humoral immunity rather than cellular immunity, and necessary functionalization of NPs is required to stimulate comprehensive immune responses. Inorganic nanomaterials have been applied to improve the efficiency of antigen delivery and immunogenicity because of their rigid structures, long shelf life, and the capability to tailor their intrinsic adjuvant-like properties and immunomodulatory functions [18]. Among them, metal oxide clusters (MOCs) are promising candidates since their interaction with biomacromolecules can be facilely designed via regulating their morphologies and surface structures to enhance their beneficial activities on the biological systems [19-21]. MOCs have been demonstrated to have direct or synergistic antibacterial activities [22,23], and the tailor-made MOCs systems, such as virus-like assemblies of MOCs with polymers, excavate a variety of nanocomposites and organic-inorganic hybrids with improved biocompatibility and target activity in anticancer drug delivery systems [21,24-26]. Therefore, it would be a beneficial attempt to explore vaccines 
combined with MOCs to induce qualitatively diverse and longlasting protective immune response [27]. Herein, to enhance BCG trained immunity effects, we develop vaccine adjuvants based on supra-particle assemblies (SPAs) assembled via non-covalent interaction. The enriched hydrogen bonding donor sites (e.g., hydroxy, amine, and amide groups) in antigens and MOCs enable their strong association on the surface of hydrogen bonding acceptor-enriched polymers, e.g., poly(4-vinylpyridine) (P4VP). The co-assembled SPAs of MOCs and antigens of M. bovis with P4VP exhibit high antigen loading and entrapment efficiency. MOCs on the supra-particle surface present the great synergy with P4VP and antigens of $M$. bovis to enhance the immunogenicity. Our SPA-based vaccine adjuvant can elicit cellular immune responses to promote the activation and multiplication of $\mathrm{T}$ lymphocyte, which is absent in most existing nano-vaccines. No sign of toxicity and mortality was observed in all the tested parameters of SPAs-treated animal models, confirming their great potential in practical medical applications.

\section{Results and discussion}

\subsection{The design of co-assembly strategy and structural characterizations of supra-particle assemblies}

To design vaccines that recapitulate the efficacy of NPs and MOCs, biocompatible P4VP is used to template the co-assembly of ultrasmall iron/molybdenum oxide clusters (size: $2.5 \mathrm{~nm}$; formula: $\left\{\mathrm{Mo}_{68}^{\mathrm{v}_{6}} \mathrm{Mo}_{4}^{\mathrm{v}} \mathrm{Fe}^{\mathrm{II}}{ }_{30} \mathrm{O}_{252}\left(\mathrm{CH}_{3} \mathrm{CO}_{2}\right)_{16}\left(\mathrm{H}_{2} \mathrm{O}\right)_{100}\right\}$ ) with antigens separated from $M$. bovis. As quasi-spherical metal oxide clusters [28], $\left\{\mathrm{Mo}_{72} \mathrm{Fe}_{30}\right\}$ clusters share the common structural feature with most biomacromolecules whose surfaces are rich in hydrogen bonding donor sites that can bridge their assembly with P4VP via multiple hydrogen bonding into SPAs [29]. Thus, the co-assembly protocol provides potential route to prepare colloidal supraparticles carrying both of the two species (MOCs and whole soluble proteins extracted from $M$. bovis) to serve as virus-like complex nano-vaccines. By following the co-assembly protocol (Fig. 1(a)), the antigens, $\left\{\mathrm{Mo}_{72} \mathrm{Fe}_{30}\right\}$, and antigen \& $\left\{\mathrm{Mo}_{72} \mathrm{Fe}_{30}\right\}$ mixtures are all able to co-assemble with $\mathrm{P} 4 \mathrm{VP}$ into virus-like SPAs under acidic condition $(\mathrm{pH}=6.6)$, which are named as $\mathrm{Mb} @ \mathrm{P} 4 \mathrm{VP}, \quad\left\{\mathrm{Mo}_{72} \mathrm{Fe}_{30}\right\} @ \mathrm{P} 4 \mathrm{VP}, \quad$ and $\mathrm{Mb} /\left\{\mathrm{Mo}_{72} \mathrm{Fe} 30\right\} \mathrm{P} 4 \mathrm{VP}$, respectively.
The morphologies of $\mathrm{Mb} /\left\{\mathrm{Mo}_{72} \mathrm{Fe}_{30}\right\} @ \mathrm{P} 4 \mathrm{VP}$ and $\mathrm{Mb} @ \mathrm{P} 4 \mathrm{VP}$ virus-like co-assemblies are characterized by light scattering techniques as spherical SPAs, suggested by the angular independent hydrodynamic radius $\left(R_{\mathrm{h}}\right)$ (Fig. 1(b) and Fig. S1 in the Electronic Supplementary Material (ESM)). M. bovis antigens are positively charged and therefore, both $\mathrm{Mb} /\left\{\mathrm{Mo}_{72} \mathrm{Fe}_{30}\right\} @ \mathrm{P} 4 \mathrm{VP}$ and Mb@P4VP SPAs, suggested from zeta potential studies, carry positive charges in phosphate buffered saline (PBS) buffers in contrast to the negative charged nature of $\left\{\mathrm{Mo}_{72} \mathrm{Fe}_{30}\right\} @ \mathrm{P} 4 \mathrm{VP}$ SPAs (Fig. 1(c)). The charges of SPAs confirm the presence of M. bovis antigens on P4VP (Fig. 1(c) and Fig. S2 in the ESM), which is consistent with the results of Fourier-transform infrared (FT-IR) measurements (Fig. S3 in the ESM). Due to their high surface areas, the synthesized SPAs exhibit high antigen loading and entrapment efficiency with average loading amount of $M$. bovis antigens on the SPAs as $0.3 \mathrm{~g} / \mathrm{g}$ (antigen/P4VP). Suggested from scanning electron microscopy (SEM) studies, the virus-like SPAs of $\mathrm{Mb} /\left\{\mathrm{Mo}_{72} \mathrm{Fe}_{30}\right\} @ \mathrm{P} 4 \mathrm{VP}$ show uniform size distribution with distinct roughness when compared with that of pure P4VP (Fig. 1(d) and Fig. S1 in the ESM), resulting from the close packing of M. bovis antigens and $\left\{\mathrm{Mo}_{72} \mathrm{Fe}_{30}\right\}$ on SPA surface. Additionally, the extended energy dispersive X-ray (EDX) spectrometry studies indicate that elements of $S$ and Mo are concentrated and evenly dispersed on the spherical SPAs (Fig. 1(e)), confirming the coexistence of M. bovis antigens and $\left\{\mathrm{Mo}_{72} \mathrm{Fe}_{30}\right\}$ on the SPAs. The coassembled SPAs are stable in typical buffers with broad $\mathrm{pH}$ ranges (in water, PBS, citrate/disodium hydrogen phosphate, and Tris$\mathrm{HCl}$, and in $\mathrm{PBS}$ of $\mathrm{pH}=6-8$ ) as shown in Figs. $\mathrm{S} 4$ and $\mathrm{S} 5$ in the ESM. No obvious changes on their morphologies can be detected for $\mathrm{Mb} /\left\{\mathrm{Mo}_{72} \mathrm{Fe}_{30}\right\} @ \mathrm{P} 4 \mathrm{VP}$ SPAs over 4 weeks when stored at $4{ }^{\circ} \mathrm{C}$ (Fig. 1(f) and Fig. S6 in the ESM), confirming their high stability for potential applications in vaccines. Meanwhile, no apparent cytotoxicity can be induced from the existence of $\left\{\mathrm{Mo}_{72} \mathrm{Fe}_{30}\right\} @ \mathrm{P} 4 \mathrm{VP}$ and P4VP, ensuring their safety as vaccine adjuvants (Fig. S7 in the ESM).

\subsection{Immune stimulation by $\mathrm{Mb} /\left\{\mathrm{Mo}_{72} \mathrm{Fe}_{30}\right\} @ \mathrm{P} 4 \mathrm{VP}$ supra- particle assemblies}

The key steps to trigger immune response are the integration of information about vaccine or microbe by dendritic cells (DCs) and macrophages [30] and the translation of the information to antigen-specific T cells and B cells. DCs and macrophages uptake (a)
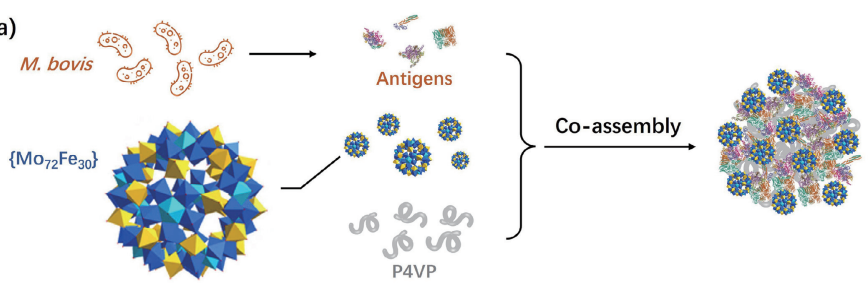

(c)

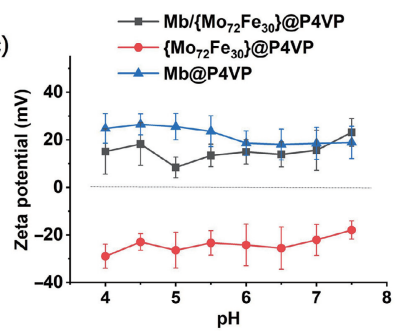

(d)

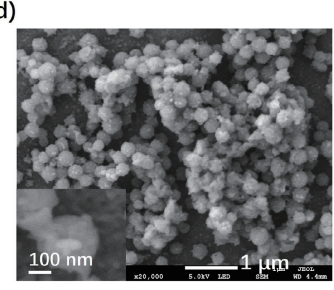

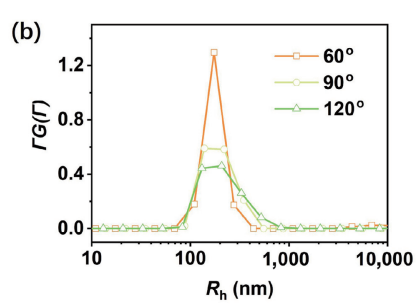

(e)

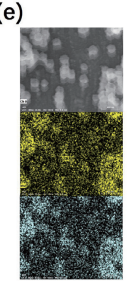

(f)

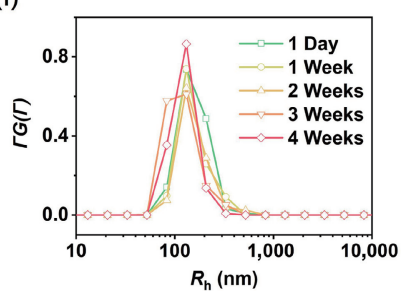

Figure 1 The design and structural characterizations of $\mathrm{Mb} /\left\{\mathrm{Mo}_{72} \mathrm{Fe}_{30}\right\} @ \mathrm{P} 4 \mathrm{VP}$ supra-particle assemblies. (a) Schematic illustration for co-assembling $\mathrm{Mb} /\left\{\mathrm{Mo}_{72} \mathrm{Fe}_{30}\right\} @ \mathrm{P} 4 \mathrm{VP}$ SPAs. (b) $R_{\mathrm{h}}$ distributions of $\mathrm{Mb} /\left\{\mathrm{Mo}_{72} \mathrm{Fe}_{30}\right\} @ \mathrm{P} 4 \mathrm{VP}$ SPAs at different angles. (c) Zeta potential of $\mathrm{Mb} /\left\{\mathrm{Mo}_{72} \mathrm{Fe}_{30}\right\} @ \mathrm{P} 4 \mathrm{VP}, \mathrm{Mb} @ \mathrm{P} 4 \mathrm{VP}$, and $\left\{\mathrm{Mo}_{72} \mathrm{Fe}_{30}\right\} @ \mathrm{P} 4 \mathrm{VP}$ SPAs at different $\mathrm{pH}$. The data show mean \pm standard error of the mean (sem) from a representative experiment $(n=3)$ out of 3 independent experiments. (d) SEM images and high-magnification SEM image (inset) of $\mathrm{Mb} /\left\{\mathrm{Mo}_{72} \mathrm{Fe}_{30}\right\} @ P 4 \mathrm{VP}$ SPAs. (e) SEM-EDX elemental mapping images of $\mathrm{Mb} /\left\{\mathrm{Mo}_{72} \mathrm{Fe}_{30}\right\} @ \mathrm{P} 4 \mathrm{VP}$ SPAs for Mo (middle) and $\mathrm{S}$ (below). (f) $R_{\mathrm{h}}$ distributions of $\mathrm{Mb} /\left\{\mathrm{Mo}_{72} \mathrm{Fe}_{30}\right\} @ \mathrm{P} 4 \mathrm{VP}$ SPAs in PBS at $4{ }^{\circ} \mathrm{C}$ for 4 weeks. 
external antigenic proteins after subcutaneous inoculation. To evaluate the cell internalization ability of $\left\{\mathrm{Mo}_{72} \mathrm{Fe}_{30}\right\} @ \mathrm{P} 4 \mathrm{VP}$, $\left\{\mathrm{Mo}_{72} \mathrm{Fe}_{30}\right\} @ \mathrm{P} 4 \mathrm{VP}$ was combined with anti-mouse Immunoglobulin G-fluorescein isothiocyanate (IgG-FITC) antibody, and the uptake of IgG-FITC was examined by flow cytometry. Murine bone marrow derived dendritic cells (BMDCs) co-incubated with IgG@P4VP or IgG/ $\left\{\mathrm{Mo}_{72} \mathrm{Fe}_{30}\right\} @ P 4 V P$ uptake 2 times more IgG than that with IgG alone (Fig. S8 in the ESM).

To test the stimulating immune response capability of SPAs in mice, female $\mathrm{Balb} / \mathrm{c}$ mice were subcutaneously vaccinated with $\mathrm{Mb} /\left\{\mathrm{Mo}_{72} \mathrm{Fe}_{30}\right\} @ \mathrm{P} 4 \mathrm{VP}$ SPAs diluted with PBS ( $\left.\mathrm{pH}=7.0\right)$. All the animal experiments were approved by the Institutional Animal Care and Use Committee at South China University of Technology (SYXK2017-0178) and were conducted strictly under the Principles of Laboratory Animal Care. The vaccinated mice were kept for 12 weeks while no sign of toxicity, no mortality, and no fever or other symptoms were observed in all the tested parameters of SPAs-treated animal models (Tables S1 and S2 and Figs. S9-S13 in the ESM). $\left\{\mathrm{Mo}_{72} \mathrm{Fe}_{30}\right\}$ on the nanocomposite surface presents the synergy with P4VP and M. bovis antigens to enhance the immunogenicity (Fig. 2(a)). The mice inoculated with $\mathrm{Mb} /\left\{\mathrm{Mo}_{72} \mathrm{Fe}_{30}\right\} @ \mathrm{P} 4 \mathrm{VP}$ keep higher titers of serum TB-specific IgG antibody compared to Mb@P4VP-treated groups for 6 weeks (Fig. 2(b)), and maintain comparable titer level with BCG groups for the next 6 weeks (Fig. S14 in the ESM). For the BCG inoculated mice, TB-specific IgG antibody at the 6th week falls more than a half by its level after the first week. While the antibody in $\mathrm{Mb} /\left\{\mathrm{Mo}_{72} \mathrm{Fe}_{30}\right\} @ \mathrm{P} 4 \mathrm{VP}$ group at the 6th week remains high at $67.9 \%$ of its level at the 1 st week.

After uptaken by macrophages, antigens accumulate in the draining lymph nodes (dLNs) and activate the germinal center (GC). GC reactions produce high affinity antibody-secreting plasma cells and memory B-cells necessary for the host defense against invading pathogens [31]. Follicular helper T cells prime $\mathrm{B}$ cells to initiate extrafollicular and germinal center antibody responses, which are crucial for affinity maturation and maintenance of humoral memory $[32,33]$. Consistently, an obvious increase of B cells and follicular helper T cells in GC was also observed one week after inoculation in the
$\mathrm{Mb} /\left\{\mathrm{Mo}_{72} \mathrm{Fe}_{30}\right\} @ \mathrm{P} 4 \mathrm{VP}$ treated groups (Fig. 2(c)), indicating that $\left\{\mathrm{Mo}_{72} \mathrm{Fe}_{30}\right\}$ and P4VP components of SPAs would facilitate the long-term persistence of the antigens in dLNs and promote the activation of GC. Each antigen-loaded SPA acts as nanosized reservoir to induce long-lasting depot effect. Compared to systemic routes of immunization with BCG, vaccination with $\mathrm{Mb} /\left\{\mathrm{Mo}_{72} \mathrm{Fe}_{30}\right\} @ P 4 V P$ SPAs induces comparable antigen specific IFN- $\gamma$ T cell responses in both lungs and spleens of Balb/c mice one week after inoculation (Figs. 2(d) and 2(e)). Collectively, $\left\{\mathrm{Mo}_{72} \mathrm{Fe}_{30}\right\}$ and $\mathrm{P} 4 \mathrm{VP}$ in $\mathrm{Mb} /\left\{\mathrm{Mo}_{72} \mathrm{Fe}_{30}\right\} @ \mathrm{P} 4 \mathrm{VP}$ SPAs as vaccine adjuvants enhance both the magnitude and duration of immune responses of mice to $M$. bovis antigens.

\section{3 $\mathrm{Mb} /\left\{\mathrm{Mo}_{72} \mathrm{Fe}_{30}\right\} @ P 4 \mathrm{VP}$ SPAs promote humoral and cellular immune responses}

To verify the enhanced immunogenicity of $\mathrm{Mb} /\left\{\mathrm{Mo}_{72} \mathrm{Fe}_{30}\right\} @ \mathrm{P} 4 \mathrm{VP}$ SPAs, the production of $\mathrm{CD}^{+}$and $\mathrm{CD}^{+}$cells was further examined. Local DCs uptake and present antigens, then induce the activation and differentiation of naive $\mathrm{T}$ lymphocytes $[34,35]$, $\mathrm{CD} 4^{+} \mathrm{Th}$ cells, and $\mathrm{CD} 8^{+}$cells. It is well-known that B cells mainly regulate the humoral immunity, whereas $\mathrm{T}$ cells regulate cellular immunity. Mice inoculated with $\mathrm{Mb} /\left\{\mathrm{Mo}_{72} \mathrm{Fe}_{30}\right\} @ \mathrm{P} 4 \mathrm{VP}$ SPAs produce more $\mathrm{B}$ cells and $\mathrm{T}$ cells than the saline group. Humoral immunity produces an antibody-mediated immune response, whereas cellular immunity produces a cell-mediated immune response. For safety, the endotoxin levels of the formulations are determined (Fig. 3(a)) and the in vivo safety of $\mathrm{Mb} /\left\{\mathrm{Mo}_{72} \mathrm{Fe}_{30}\right\} @ \mathrm{P} 4 \mathrm{VP}$ SPAs is verified (Table S2 in the ESM). All the tested formulations are in a relatively low range of endotoxin level. No significant differences among the groups are observed, indicating the safety of the adjuvants $\left\{\mathrm{Mo}_{72} \mathrm{Fe}_{30}\right\} @$ P4VP SPAs. Following the safety evaluation of $\left\{\mathrm{Mo}_{72} \mathrm{Fe}_{30}\right\} @ P 4 V P$ SPAs, the production of $\mathrm{CD}^{+}$and $\mathrm{CD}^{+}$cells in mice is determined. In the antigen-specific immune investigation, $\mathrm{Mb} /\left\{\mathrm{Mo}_{72} \mathrm{Fe}_{30}\right\} @ \mathrm{P} 4 \mathrm{VP}$ SPAs maintain high titers of serum anti-TB antibody over time (Fig. 2(b)), promoting the humoral immunity. After vaccination, compared with saline group, the production of $\mathrm{CD} 4^{+}$and $\mathrm{CD}^{+}$ cells in $\mathrm{Mb} /\left\{\mathrm{Mo}_{72} \mathrm{Fe}_{30}\right\} @ \mathrm{P} 4 \mathrm{VP}$-injected mice is distinctly increased (Figs. 3(b) and 3(c), and Fig. S15 in the ESM). BCG significantly
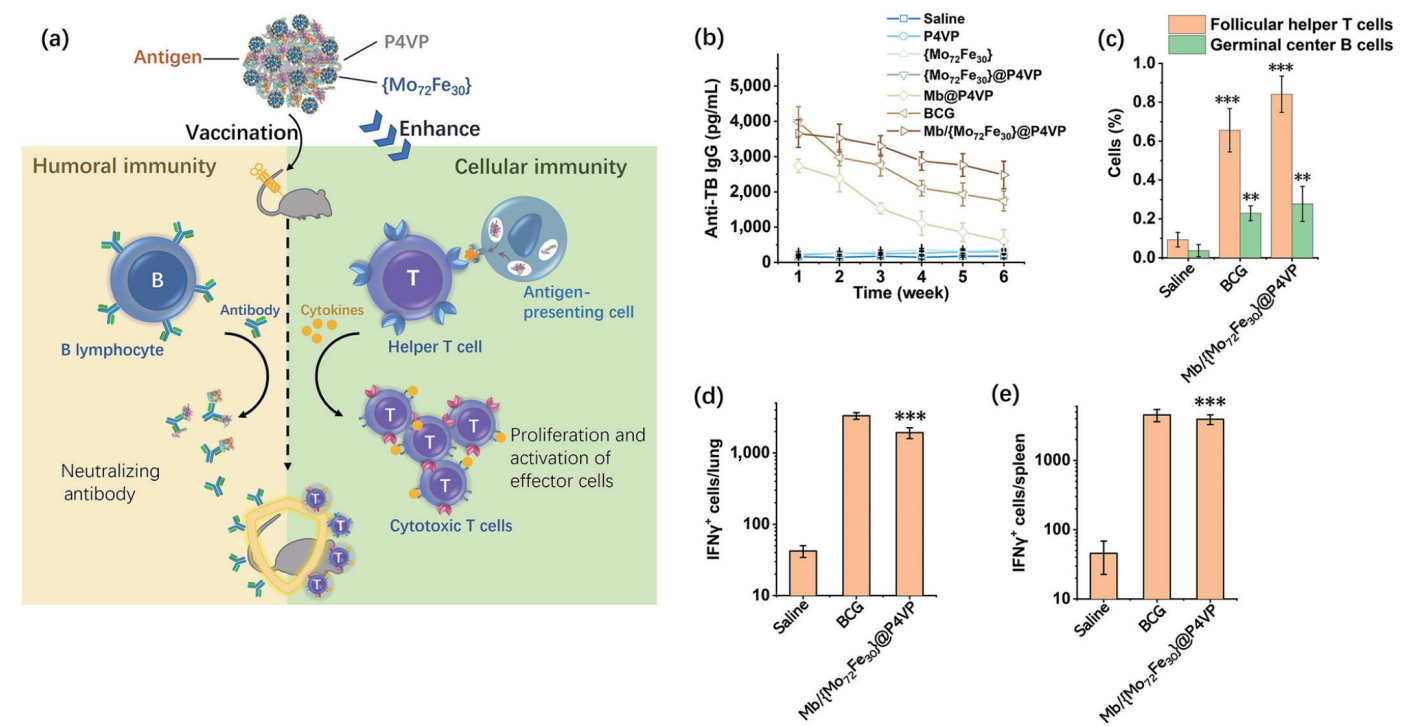

Figure 2 Enhanced immune stimulation by $\mathrm{Mb} /\left\{\mathrm{Mo}_{72} \mathrm{Fe}_{30}\right\} @ \mathrm{P} 4 \mathrm{VP}$ SPAs. (a) Schematic illustration of enhanced immune stimulation by $\mathrm{Mb} /\left\{\mathrm{Mo}_{72} \mathrm{Fe}_{30}\right\} @ \mathrm{P} 4 \mathrm{VP}$ SPAs. (b) Serum TB-specific IgG titres over time (Balb/c mice, $n=6$ for each group). (c) Count rates of follicular helper T cells and germinal center B cells in mice inguinal lymph nodes by flow cytometry one-week after inoculation. Each data show mean \pm sem from a representative experiment $(n=6$ for each group in (b) and (c) out of three independent experiments). IFN $\gamma$ responses determined by antigen-driven ELISPOT assays in (d) lung or in (e) spleen one week after vaccination with saline, $\mathrm{BCG}$, or $\mathrm{Mb} /\left\{\mathrm{Mo}_{72} \mathrm{Fe}_{30}\right\} @ \mathrm{P} 4 \mathrm{VP}$. Each data show mean \pm sd from a representative experiment $\left(n=4\right.$ in (d) and (e)). ${ }^{*} p<0.05,{ }^{* *} p<0.01$, and ${ }^{* * *} p<0.001$ are analyzed by one-way ANOVA. * indicates statistically significant differences between $\mathrm{Mb} /\left\{\mathrm{Mo}_{72} \mathrm{Fe}_{30}\right\} @ \mathrm{P} 4 \mathrm{VP}$ groups and saline groups. 
(a)

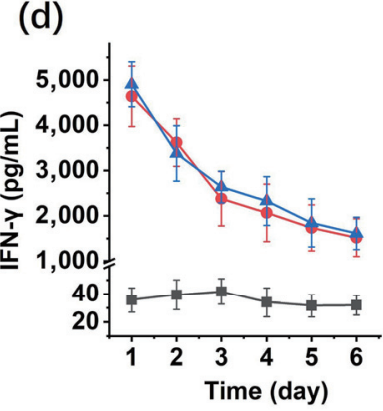

(b)

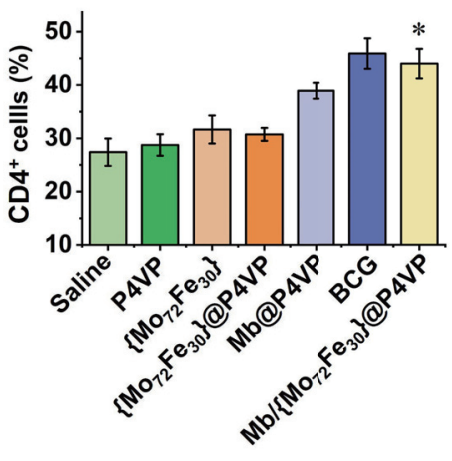

(c)

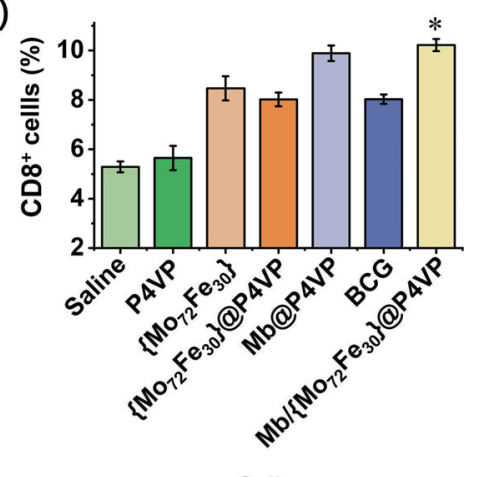

(e)

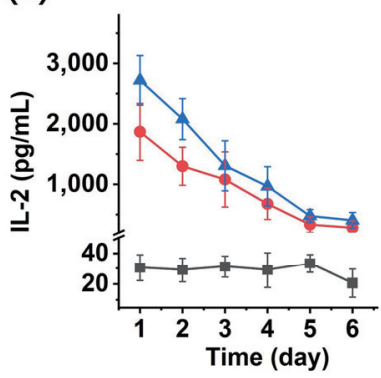

(f)

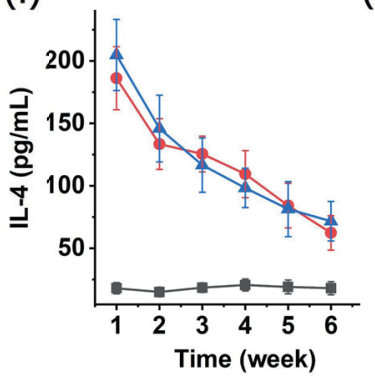

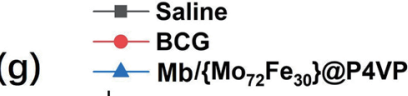

g)

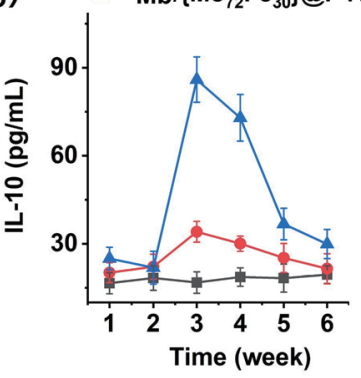

Figure 3 (a) Endotoxin levels of P4VP, $\left\{\mathrm{Mo}_{72} \mathrm{Fe}_{30}\right\} @ \mathrm{P} 4 \mathrm{VP}$, and $\mathrm{Mb} /\left\{\mathrm{Mo}_{72} \mathrm{Fe}_{30}\right\} @ \mathrm{P} 4 \mathrm{VP}$ detected via chromogenic limulus amebocyte lysate (LAL) endotoxin assay kit. Each data show mean $\pm \mathrm{sd}$ from a representative experiment $(n=4)$. Count rates of (b) $\mathrm{CD} 4^{+}$and $(\mathrm{c}) \mathrm{CD} 8^{+}$cells in Balb/c mice spleen by flow cytometry one-week after inoculation ( $n=6$ for each group). Cytokine release induced by $\mathrm{Mb} /\left\{\mathrm{Mo}_{72} \mathrm{Fe}_{30}\right\} @$ P4VP SPAs: (d) IFN- $\gamma$, (e) IL-2, (f) IL-4, and (g) IL-10. Serum cytokines were determined by ELISA method.

stimulates the production of $\mathrm{CD}^{+}$cells with little stimulating effect on the production of $\mathrm{CD}^{+}$cell. In addition, the increasement of $\mathrm{CD}^{+}$cell production exhibits spatiotemporal hysteresis. $\mathrm{CD}^{+}$cell production of BCG-injected mice peaks slower than the production of $\mathrm{CD}^{+}$cell. Most existing nanovaccines elicit a targeted antibody response, nevertheless, safely activating cellular immunity against many infectious diseases remains a challenging task. As a prerequisite for cellular immunity, the proportion of IFN- $\gamma$-secreting $\mathrm{CD}^{+} \mathrm{T}$ cells (Figs. 2(e) and $3(\mathrm{c}))$ in $\mathrm{Mb} /\left\{\mathrm{Mo}_{72} \mathrm{Fe}_{30}\right\} @ \mathrm{P} 4 \mathrm{VP}$ group increases by $42.8 \%$ at the end of the first weeks. CD8 ${ }^{+} \mathrm{T}$ cells play an important role in mediating the immune response to tuberculosis in spleen, suggesting that $\mathrm{CD} 8^{+} \mathrm{CTL}$ response is critical for the control of tuberculosis spread in viscera [36]. The increase of $\mathrm{CD} 8^{+}$cells in spleen indicates $\mathrm{Mb} /\left\{\mathrm{Mo}_{72} \mathrm{Fe}_{30}\right\} @ \mathrm{P} 4 \mathrm{VP}$ SPAs can control the spread of bacteria in extrapulmonary organs. Also, $\left\{\mathrm{Mo}_{72} \mathrm{Fe}_{30}\right\}$ and P4VP components as vaccine adjuvants stimulate both $\mathrm{CD} 4^{+}$and $\mathrm{CD}^{+}$cells for antigen presenting and cellular immune response.

Further, Balb/c mice serums treated with $\mathrm{Mb} /\left\{\mathrm{Mo}_{72} \mathrm{Fe}_{30}\right\} @ \mathrm{P} 4 \mathrm{VP}$ were collected to test the cytokine release in eliciting humoral and cellular immune responses. Compared with control groups, the concentrations of Th1 cytokines IFN- $\gamma$ and IL-2 are increased immediately after inoculation and gradually decreased in the next few days (Figs. 3(d) and 3(e)), which is conducive to the protective immune response against tuberculosis. Similarly, Th2 cytokines IL-4 and IL-10 are also increased after inoculation (Figs. 3(f) and 3(g)), and the concentration of IL-10 peaks at the 3 rd week. IFN- $\gamma$ and IL-2 play a major role in establishing cellular immunity, while IL- 4 and IL-10 are humoral factors involved in the suppressive function of regulatory $\mathrm{T}$ cells [37]. IL-10 cytokines play critical roles in maintaining immune homeostasis [38]. In the later stage, the concentration of IL-10 increases as the antigens are gradually cleared, hence the body secretes anti-inflammatory cytokines to neutralize inflammation in order to prevent the cytokine storm. Through the comparison of cytokine release profiles, $\left\{\mathrm{Mo}_{72} \mathrm{Fe}_{30}\right\}$ and $\mathrm{P} 4 \mathrm{VP}$ components of
SPAs exhibit potent Th-mediated responses. In prophylactic treatment, the activation of $\mathrm{B}$ cells by vaccine to produce specific neutralizing antibodies also requires the assistance of Th cells. Cellular immune response determines the vaccine protective cellular immunity and regulates the induction of humoral immunity. Because of their safety profiles, protein-based subunit vaccines are exploited to replace the live attenuated vaccines, such as BCG. To elicit an immune response strong enough for protection from infection by an intracellular pathogen, an adjuvant is required in a subunit vaccine. Our $\left\{\mathrm{Mo}_{72} \mathrm{Fe}_{30}\right\}$ and P4VP components of SPAs as vaccine adjuvants not only improve the magnitude and durability of antibody responses but also improve T cell-derived cytokine patterns, leading to the enhanced humoral and cellular immune responses.

\section{Conclusions}

A versatile protocol based on polymer-templated assembly strategy is proposed for the facile complexation of vaccines and adjuvants through non-covalent interactions. The sub-nanosized, water-soluble $\left\{\mathrm{Mo}_{72} \mathrm{Fe}_{30}\right\}$ clusters with well-defined composition and molecular structure are used as vaccine adjuvants. $\left\{\mathrm{Mo}_{72} \mathrm{Fe}_{30}\right\}$ and $\mathrm{P} 4 \mathrm{VP}$ are co-assembled with antigenic proteins, and virus-like supra-particle assemblies of $\mathrm{Mb} /\left\{\mathrm{Mo}_{72} \mathrm{Fe}_{30}\right\} @ \mathrm{P} 4 \mathrm{VP}$ are formed in buffer solution. $\mathrm{Mb} /\left\{\mathrm{Mo}_{72} \mathrm{Fe}_{30}\right\} @ \mathrm{P} 4 \mathrm{VP}$ virus-like SPAs enhance T cell immune response which is highly required in BCG vaccine, since $\mathrm{BCG}$ vaccine induces incongruous $\mathrm{T}$ cell immunity in immune protection against tuberculosis. $\mathrm{Mb} /\left\{\mathrm{Mo}_{72} \mathrm{Fe}_{30}\right\} @ \mathrm{P} 4 \mathrm{VP}$ SPAs can also elicit comparable cellular immune activation which is often hysteretic in BCG immune protection. Compared with pure $M$. bovis antigenic proteins, $\left\{\mathrm{Mo}_{72} \mathrm{Fe}_{30}\right\}$ and $\mathrm{P} 4 \mathrm{VP}$ components in $\mathrm{Mb} /\left\{\mathrm{Mo}_{72} \mathrm{Fe}_{30}\right\} @ \mathrm{P} 4 \mathrm{VP}$ SPAs can significantly increase the immune protection of vaccines and are potential adjuvant candidates for inclusion in vaccines against tuberculosis. Collectively, the co-assembly method provides the protection against the intractable Mycobacterium infection, opens an avenue 
of loading antigens for vaccine delivery, and augments the loaded vaccines in low cost and large-scale production.

\section{Experimental methods}

\subsection{Assembling of nanocomposites}

Preparation of $\left\{\mathrm{Mo}_{72} \mathrm{Fe}_{30}\right\}$ was following the Refs. [39, 40]. Considering the ability of $\left\{\mathrm{Mo}_{72} \mathrm{Fe}_{30}\right\}$ that can be self-assemble into blackberry-type structure [41] and the stability of the protein antigens, the co-assembly protocol used the freshly prepared $\left\{\mathrm{Mo}_{72} \mathrm{Fe}_{30}\right\}$ and was carried out in an ice bath. In addition, constrained by microbiology lab containment, $M$. bovis bacteria were inactivated and disrupted, and the whole soluble proteins were extracted and used as stimulating antigens to co-assemble the $\mathrm{Mb} /\left\{\mathrm{Mo}_{72} \mathrm{Fe}_{30}\right\} @ \mathrm{P} 4 \mathrm{VP}$ SPAs. The detailed co-assembly procedure is as follows: $0.1 \mathrm{~mL}$ of bacterial proteins $(10 \mathrm{mg} / \mathrm{mL})$ in the vial containing a stirrer was added dropwise with $0.5 \mathrm{~mL}$ of P4VP solution $(2 \mathrm{mg} / \mathrm{mL})$ along with colloids forming, followed by adding $0.25 \mathrm{~mL}\left\{\mathrm{Mo}_{72} \mathrm{Fe}_{30}\right\}(5 \mathrm{mg} / \mathrm{mL})$ dropwise. The assembled SPAs were characterized by dynamic light scattering (DLS), SEM, and FTIR. FTIR transmittance spectra (Fig. S2 in the ESM) of pyridine rings region for $\mathrm{Mb} @ \mathrm{P} 4 \mathrm{VP}$ and $\mathrm{Mb} /\left\{\mathrm{Mo}_{72} \mathrm{Fe}_{30}\right\} @ \mathrm{P} 4 \mathrm{VP}$ SPAs showed distinct peaks at $\sim 1,599 \mathrm{~cm}^{-1}$, suggesting that these two kinds of SPAs were composed of P4VP. Additionally, the peaks at $1,556,1,416,1,225$, and $1,068 \mathrm{~cm}^{-1}$ observed in the spectra of $\mathrm{Mb} @ \mathrm{P} 4 \mathrm{VP}$ and $\mathrm{Mb} /\left\{\mathrm{Mo}_{72} \mathrm{Fe}_{30}\right\} @ \mathrm{P} 4 \mathrm{VP}$ SPAs were the characteristic patterns for P4VP. The characteristic peaks at 1,624 and $780 \mathrm{~cm}^{-1}$ assigned to $v(\mathrm{OH})$ and $v(\mathrm{Me}[\mathrm{Mo}, \mathrm{Fe}]-\mathrm{O}-\mathrm{Mo})$ for $\left\{\mathrm{Mo}_{72} \mathrm{Fe}_{30}\right\}$, were red-shifted to 1,619 and $774 \mathrm{~cm}^{-1}$ for $\mathrm{Mb} /\left\{\mathrm{Mo}_{72} \mathrm{Fe}_{30}\right\} @ \mathrm{P} 4 \mathrm{VP}$ SPAs respectively, confirming that $\left\{\mathrm{Mo}_{72} \mathrm{Fe}_{30}\right\}$ were loading on the SPAs. Keeping the biofunctionality of $M$. bovis antigens is critical for the SPAs to exert their immunity.

\subsection{Sample collection and storage}

All the animals were raised in accordance with the National Standard Regulating Welfare of Laboratory Test Animals. The animal study protocol was approved by the Institutional Animal Care and Use Committee at South China University of Technology (SYXK2017-0178). Female Balb/c mice, aged 6-8 week, were purchased from Shanghai Jiesijie Laboratory Animal Co., Ltd. After one-week acclimation, Balb/c mice were divided into 7 groups. $20 \mu \mathrm{L}$ of the samples was inoculated subcutaneously in the back of Balb/c mice, separately, and the control mice were injected with saline. Serum and plasma samples were collected every week to test the concentration of IFN- $\gamma$, IL-2, IL-4, IL-10, and anti-TB-IgG by using enzyme-linked immunosorbent assay (ELISA) kits following the manufacturer's instruction. In order to measure the concentration of IFN- $\gamma$, IL-2, IL-4, IL-10, and antiTB-IgG in the serum sample, their ELISA kits including a set of calibration standards were applied. The calibration standards were assayed at the same time as the samples and allowed the operator to produce a standard curve of optical density vs. IFN- $\gamma$, IL-2, IL-4, IL-10, and anti-TB-IgG concentration. The concentration of IFN$\gamma$, IL-2, IL-4, IL-10, and anti-TB-IgG in the samples was then determined by comparing the OD of the samples to the standard curve. Mouse spleen mononuclear cells were separated by using cell isolation solution kits following the manufacturer's instruction. The $\mathrm{CD}^{+}$and $\mathrm{CD} 8^{+}$lymphocytes in mice spleen were analyzed by immunophenotypic method (eBioscience ${ }^{\mathrm{TM}}$ ) and counted by flow cytometry.

The serum samples were collected as follows. Before centrifugation for $10 \mathrm{~min}$ at approximately $3,000 \mathrm{~g}$, the sample in a serum separator tube was allowed to clot for $30 \mathrm{~min}$. Then the serum was removed, and the samples were assayed immediately. The plasma was collected using EDTA or heparin as an anticoagulant. The samples were centrifuged for $30 \mathrm{~min}$ at $3,000 \mathrm{~g}$ at $2-8{ }^{\circ} \mathrm{C}$. The samples were collected and stored at -20 or $-80^{\circ} \mathrm{C}$. The samples of cell culture supernates and other biological fluids were centrifuged to remove particulates and assayed immediately. During the operation process, the repeated freezethaw cycles were avoided.

\subsection{Evaluation of the internalization of antigens}

To investigate the antigen uptake, BMDC cells were incubated with anti-mouse IgG-FITC antibody (IgG), IgG@P4VP, and $\mathrm{IgG} /\left\{\mathrm{Mo}_{72} \mathrm{Fe}_{30}\right\} @ P 4 V P$ for $2 \mathrm{~h}$, respectively. The antibody dilution for flow cytometry staining was performed according to the manufacturer's instructions. Generally, a 1:100 antibody dilution was employed for $10^{7}$ cells. To evaluate the cytotoxicity, BMDC cells were incubated with $\left\{\mathrm{Mo}_{72} \mathrm{Fe}_{30}\right\} @ \mathrm{P} 4 \mathrm{VP},\left\{\mathrm{Mo}_{72} \mathrm{Fe}_{30}\right\}$, and P4VP for $2 \mathrm{~h}$, respectively. Cell viability was assessed using the CCK-8 kit.

\subsection{Evaluation of germinal center activation}

To investigate the germinal center activation and antigen persistence, $\mathrm{Balb} / \mathrm{c}$ mice were subcutaneously injected with $\mathrm{Mb} /\left\{\mathrm{Mo}_{72} \mathrm{Fe}_{30}\right\} @ \mathrm{P} 4 \mathrm{VP}, \quad\left\{\mathrm{Mo}_{72} \mathrm{Fe}_{30}\right\} @ \mathrm{P} 4 \mathrm{VP}, \quad \mathrm{Mb} @ \mathrm{P} 4 \mathrm{VP}, \quad$ and $\mathrm{Mb} /\left\{\mathrm{Mo}_{72} \mathrm{Fe}_{30}\right\}$ nanocomposites, and $\left\{\mathrm{Mo}_{72} \mathrm{Fe}_{30}\right\}, \mathrm{P} 4 \mathrm{VP}$, and BCG, respectively. On the seventh day, mice were euthanized, and their inguinal lymph nodes were stripped out in order to prepare single cell suspensions. Germinal center B cells and follicular helper T cells were labelled with antibodies (FITC rat anti-mouse T- and Bcell activation antigen, Cy5.5 rat anti-mouse CXCR5 from BD, and rabbit anti-CD278/ICOS monoclonal antibody). The antibody dilution for flow cytometry staining was carried out according to the manufacturer's instructions. Each experiment was repeated three times.

\subsection{Statistical analysis}

Analysis of variance ANOVA was used to compare independent samples from different groups for multiple group comparison. All statistical tests were performed using GraphPad Prism 8.0. All data were presented as mean \pm standard deviation (sd). ${ }^{*} p<0.05$ was considered statistically significant.

\section{Acknowledgements}

The work was supported financially by the National Natural Science Foundation of China (Nos. 22101086, 21961142018, and 51873067) and the Natural Science Foundation of Guangdong Province (Nos. 2021A1515012024 and 2021A1515010271).

Electronic Supplementary Material: Supplementary material (further structural analysis and biological analsyis) is available in the online version of this article at https://doi.org/10.1007/s12274021-4004-9.

\section{References}

[1] Ke, G. J.; Su, D. K.; Li, Y.; Zhao, Y.; Wang, H. G.; Liu, W. J.; Li, M.; Yang, Z. T.; Xiao, F.; Yuan, Y. et al. An accurate, high-speed, portable bifunctional electrical detector for COVID-19. Sci. China Mater. 2021, 64, 739-747.

[2] Escobar, L. E.; Molina-Cruz, A.; Barillas-Mury, C. BCG vaccine protection from severe coronavirus disease 2019 (COVID-19). Proc. Natl. Acad. Sci. USA 2020, 117, 27741-27742.

[3] Orme, I. M. The Achilles heel of BCG. Tuberculosis 2010, 90, 329-332.

[4] Paludan, S. R.; Pradeu, T.; Masters, S. L.; Mogensen, T. H. 
Constitutive immune mechanisms: Mediators of host defence and immune regulation. Nat. Rev. Immunol. 2021, 21, 137-150.

[5] Holmgren, J.; Czerkinsky, C. Mucosal immunity and vaccines. Nat. Med. 2005, 11, S45-S53.

[6] Fries, C. N.; Curvino, E. J.; Chen, J. L.; Permar, S. R.; Fouda, G. G.; Collier, J. H. Advances in nanomaterial vaccine strategies to address infectious diseases impacting global health. Nat. Nanotechnol. 2021, 16, 1-14.

[7] Perciani, C. T.; Liu, L. Y.; Wood, L.; MacParland, S. A. Enhancing immunity with nanomedicine: Employing nanoparticles to harness the immune system. ACS Nano 2021, 15, 7-20.

[8] Du, R. J.; Qu, Y. J.; Qi, P. X.; Sun, X. B.; Liu, Y. H.; Zhao, M. Natural flagella-templated Au nanowires as a novel adjuvant against Listeria monocytogenes. Nanoscale 2020, 12, 5627-5635.

[9] Tong, T. Y.; Guan, Y. P.; Gao, Y. J.; Xing, C. Y.; Zhang, S. Q.; Jiang, D. G.; Yang, X. W.; Kang, Y.; Pang, J. Smart nanocarriers as therapeutic platforms for bladder cancer. Nano Res. 2022, 15, 2157-2176.

[10] Li, M. M.; Zhao, X. R.; Dai, J. F.; Yu, Z. L. Peptide therapeutics and assemblies for cancer immunotherapy. Sci. China Mater. 2019, 62, $1759-1781$.

[11] Gu, Z.; Biswas, A.; Zhao, M. X.; Tang, Y. Tailoring nanocarriers for intracellular protein delivery. Chem. Soc. Rev. 2011, 40, 3638-3655.

[12] Nembrini, C.; Stano, A.; Dane, K. Y.; Ballester, M.; van der Vlies, A. J.; Marsland, B. J.; Swartz, M. A.; Hubbell, J. A. Nanoparticle conjugation of antigen enhances cytotoxic T-cell responses in pulmonary vaccination. Proc. Natl. Acad. Sci. USA 2011, 108, E989-E997.

[13] Singh, A. Eliciting B cell immunity against infectious diseases using nanovaccines. Nat. Nanotechnol. 2021, 16, 16-24.

[14] Li, X.; Pan, C.; Sun, P.; Peng, Z. H.; Feng, E. L.; Wu, J.; Wang, H. L.; Zhu, L. Orthogonal modular biosynthesis of nanoscale conjugate vaccines for vaccination against infection. Nano Res. 2022, 15, $1645-1653$.

[15] Shen, H.; Ackerman, A. L.; Cody, V.; Giodini, A.; Hinson, E. R.; Cresswell, P.; Edelson, R. L.; Saltzman, W. M.; Hanlon, D. J. Enhanced and prolonged cross-presentation following endosomal escape of exogenous antigens encapsulated in biodegradable nanoparticles. Immunology 2006, 117, 78-88.

[16] Chan, J. D.; Lai, J. Y.; Slaney, C. Y.; Kallies, A.; Beavis, P. A.; Darcy, P. K. Cellular networks controlling T cell persistence in adoptive cell therapy. Nat. Rev. Immunol. 2021, 21, 769-784.

[17] Pollard, A. J.; Bijker, E. M. A guide to vaccinology: from basic principles to new developments. Nat. Rev. Immunol. 2021, 21, 83-100.

[18] Sun, Y. Z.; Yin, Y.; Gong, L. D.; Liang, Z. C.; Zhu, C. D.; Ren, C. X.; Zheng, N.; Zhang, Q.; Liu, H. B.; Liu, W. et al. Manganese nanodepot augments host immune response against coronavirus. Nano Res. 2021, 14, 1260-1272.

[19] Bijelic, A.; Rompel, A. The use of polyoxometalates in protein crystallography-An attempt to widen a well-known bottleneck. Coord. Chem. Rev. 2015, 299, 22-38.

[20] Proust, A.; Matt, B.; Villanneau, R.; Guillemot, G.; Gouzerh, P.; Izzet, G. Functionalization and post-functionalization: A step towards polyoxometalate-based materials. Chem. Soc. Rev. 2012, 41, 7605-7622.

[21] Yang, W.; Lyu, Q. H.; Zhao, J.; Cao, L. Q.; Hao, Y.; Zhang, H. Recent advance in near-infrared/ultrasound-sensitive 2Dnanomaterials for cancer therapeutics. Sci. China Mater. 2020, 63, 2397-2428.

[22] Bijelic, A.; Aureliano, M.; Rompel, A. The antibacterial activity of polyoxometalates: Structures, antibiotic effects and future perspectives. Chem. Commun. 2018, 54, 1153-1169.

[23] Li, J. F.; Chen, Z. J.; Zhou, M. C.; Jing, J. B.; Li, W.; Wang, Y.; Wu, L. X.; Wang, L. Y.; Wang, Y. Q.; Lee, M. Polyoxometalate-driven self-assembly of short peptides into multivalent nanofibers with enhanced antibacterial activity. Angew. Chem., Int. Ed. 2016, 55, 2592-2595.
[24] Blazevic, A.; Al-Sayed, E.; Roller, A.; Giester, G.; Rompel, A. Trisfunctionalized hybrid Anderson polyoxometalates: Synthesis, characterization, hydrolytic stability and inversion of protein surface charge. Chem.-Eur. J. 2015, 21, 4762-4771.

[25] Al-Sayed, E.; Blazevic, A.; Roller, A.; Rompel, A. The synthesis and characterization of aromatic hybrid Anderson-Evans POMs and their serum albumin interactions: The shift from polar to hydrophobic interactions. Chem.-Eur. J. 2015, 21, 17800-17807.

[26] Izzet, G.; Volatron, F.; Proust, A. Tailor-made covalent organic-inorganic polyoxometalate hybrids: Versatile platforms for the elaboration of functional molecular architectures. Chem. Rec. 2017, 17, 250-266.

[27] Pulendran, B.; Ahmed, R. Translating innate immunity into immunological memory: Implications for vaccine development. Cell 2006, 124, 849-863.

[28] Besson, C.; Schmitz, S.; Capella, K. M.; Kopilevich, S.; Weinstock, I. A.; Köegerler, P. A regioselective Huisgen reaction inside a Keplerate polyoxomolybdate nanoreactor. Dalton Trans. 2012, 41, 9852-9854.

[29] Zhou, J.; Hu, J.; Li, M.; Li, H.; Wang, W. Y.; Liu, Y. Z.; Winans, R. E.; Li, T.; Liu, T. B.; Yin, P. C. Hydrogen bonding directed coassembly of polyoxometalates and polymers to core-shell nanoparticles. Mater. Chem. Front. 2018, 2, 2070-2075.

[30] Chen, J.; Lin, L; Yan, N.; Hu, Y. Y.; Fang, H.; Guo, Z. P.; Sun, P. J.; Tian, H. Y.; Chen, X. S. Macrophages loaded CpG and GNR-PEI for combination of tumor photothermal therapy and immunotherapy. Sci. China Mater. 2018, 61, 1484-1494.

[31] Hamel, K. M.; Liarski, V. M.; Clark, M. R. Germinal center B-cells. Autoimmunity 2012, 45, 333-347.

[32] Vinuesa, C. G.; Linterman, M. A.; Yu, D.; MacLennan, I. C. M. Follicular helper T cells. Аnпu. Rev. Immunol. 2016, 34, 335-368.

[33] Rydyznski, C.; Daniels, K. A.; Karmele, E. P.; Brooks, T. R.; Mahl, S. E.; Moran, M. T.; Li, C. M.; Sutiwisesak, R.; Welsh, R. M.; Waggoner, S. N. Generation of cellular immune memory and B-cell immunity is impaired by natural killer cells. Nat. Commun. 2015, 6 , 6375

[34] Zhu, W. J.; Chen, Q.; Jin, Q. T.; Chao, Y.; Sun, L. L.; Han, X.; Xu, J.; Tian, L. L.; Zhang, J. L.; Liu, T. et al. Sonodynamic therapy with immune modulatable two-dimensional coordination nanosheets for enhanced anti-tumor immunotherapy. Nano Res. 2021, 14, 212-221.

[35] Nguyen, T. L.; Cha, B. G.; Choi, Y.; Im, J.; Kim, J. Injectable dualscale mesoporous silica cancer vaccine enabling efficient delivery of antigen/adjuvant-loaded nanoparticles to dendritic cells recruited in local macroporous scaffold. Biomaterials 2020, 239, 119859.

[36] Sun, J.; Dodd, H.; Moser, E. K.; Sharma, R.; Braciale, T. J. CD4 ${ }^{+}$T cell help and innate-derived IL-27 induce Blimp-1-dependent IL-10 production by antiviral CTLs. Nat. Immunol. 2011, 12, 327-334.

[37] Fillatreau, S.; Sweenie, C. H.; McGeachy, M. J.; Gray, D.; Anderton, S. M. B cells regulate autoimmunity by provision of IL-10. Nat. Immunol. 2002, 3, 944-950.

[38] Brockmann, L.; Soukou, S.; Steglich, B.; Czarnewski, P.; Zhao, L. L.; Wende, S.; Bedke, T.; Ergen, C.; Manthey, C.; Agalioti, T. et al. Molecular and functional heterogeneity of IL-10-producing $\mathrm{CD} 4^{+} \mathrm{T}$ cells. Nat. Commun. 2018, 9, 5457.

[39] Müller, A.; Krickemeyer, E.; Bögge, H.; Schmidtmann, M.; Peters, F. Organizational forms of matter: An inorganic super fullerene and keplerate based on molybdenum oxide. Angew. Chem., Int. Ed. 1998, 37, 3359-3363.

[40] Müller, A.; Sarkar, S.; Shah, S. Q. N.; Bögge, H., Schmidtmann, M., Sarkar, S.; Kögerler, P.; Hauptfleisch, B.; Trautwein, A. X.; Schünemann, V. Archimedean synthesis and magic numbers: "Sizing" giant molybdenum-oxide-based molecular spheres of the keplerate type. Angew. Chem., Int. Ed. 1999, 38, 3238-3241.

[41] Liu, T. B.; Imber, B.; Diemann, E.; Liu, G.; Cokleski, K.; Li, H. L.; Chen, Z. Q.; Muller, A. Deprotonations and charges of well-defined $\left\{\mathrm{Mo}_{72} \mathrm{Fe}_{30}\right\}$ nanoacids simply stepwise tuned by $\mathrm{pH}$ allow control/variation of related self-assembly processes. J. Am. Chem. Soc. 2006, 128, 15914-15920. 